J O U R A L OF French and Francophone Philosophy
RE VUE DE LA

philosophie française et de langue française

\title{
Alain Badiou's Suturing of the Law to the Event and the State of Exception
}

Antonio Calcagno

Journal of French and Francophone Philosophy - Revue de la philosophie française et de langue française, Vol XXIV, No 1 (2016) 192-204.

\author{
Vol XXIV, No 1 (2016) \\ ISSN 1936-6280 (print) \\ ISSN 2155-1162 (online) \\ DOI $10.5195 /$ jffp. 2016.712 \\ www.jffp.org
}

\section{(c) EY-NC-ND}

This work is licensed under a Creative Commons Attribution-Noncommercial-No Derivative Works 3.0 United States License.

\section{ULIS D-Sunt}

This journal is operated by the University Library System of the University of Pittsburgh as part of its D-Scribe Digital Publishing Program, and is co-sponsored by the University of Pittsburgh Press 


\title{
Alain Badiou's Suturing of the Law to the Event and the State of Exception
}

\author{
Antonio Calcagno \\ King's University College, Canada
}

If one reads closely Alain Badiou's essay "The Three Negations," ${ }^{1}$ one cannot but be struck by his discussion of negation and how it clarifies the appearing and (in)existence of the event. The logic of Badiou's three negations explain how events make existents and inexistents appear in different degrees, ranging from the most intense appearings and (in)existences, which mark the significant change constitutive of events, to the milder, non-apparent shifts, to false or fictional shifts, which Badiou calls paraconsistent appearings. The relationship between law and events follows the logic of the three negations:

So the relationship between law and event is intelligible only if we clearly distinguish the three different meanings of negation. A truth, as a set of consequences of a change, is certainly transgressive in a classical context. But if the context is intuitionistic, the world continues with the same general laws, with some differences in their application. And if the context is paraconsistent, the change is only a fiction. $^{2}$

Most revealing in Badiou's discussion of law and the event is the intimate connection between them. Badiou never sees the law as an event in and of itself; rather, the law is structured by the event itself. The rupture of an event creates a new subjectivity and a new time, all of which radically break with preceding established orders or regimes. Events reorganize situations, both material and historical. Law, viewed as an element in the set of multiple elements that constitute an event, is subject to the logic of the event: the intensity of the event directly conditions the very intensity of or the degree of the existence or appearing of the law. The stronger and more forceful the event, the greater the transgressive intensity of the law. For example, the 
French Revolution, understood as an event, breaks with an old and no longer tenable monarchical view of the world. The French Revolution overturns monarchic rule and law with new laws, introduced by both Robespierre and Saint-Just. Badiou remarks:

For many sophisticated reasons, I name a Truth, or an evental-truth, the multiplicity composed of these consequences. So we can say that a truth, in a first sense, is a part of the world, because it is a set of consequences of the event in the world, and not outside. But in a second sense, we can say that a truth is like a negation of the world, because the event itself is subtracted from the rational or conventional laws of the world. We can summarize all that in one sentence: A truth is a transgression of the law. "Transgression" first signifies that a truth depends on the law, and second is nevertheless a negation of the law. ${ }^{3}$

In Badiou's account of the event, we can say that that the law is sutured to the event. We could even say that law, understood always within the specific contexts of events, is an element of most event-sets. In other words, wherever and whenever an event occurs, one will always find a transgressive element of the law.

I am sympathetic to this view, and I believe that Badiou has captured an important aspect of events with his discussion of law. But I wonder if we can even posit a more radical desuturing of the law from the event: Can radical shifts in law produce events? Can the law itself be an event, thereby conditioning the very nature of the event itself, creating a new subjectivity and a new time? I would like to argue that the law can do so. How? Badiou begins "The Three Negations" by discussing the work of the German jurist Carl Schmitt. ${ }^{4}$ I would like to argue that the state of exception, as elaborated by Carl Schmitt, can serve as the willed decision of a sovereign that brings about an event. We can understand the sovereign as a kind of legal subject who has the force to bring about a new event, thereby rupturing with an established order and introducing a new form of subjectivity and time.

\section{Law and the Event}

Bruno Bosteels make clear that the concept of law is used in various senses in Badiou's work. ${ }^{5}$ He indicates that we see the law operating in Badiou's early work, The Theory of the Subject, and that we also see it in Badiou's later work. Bosteels shows how the notion of the transgressive law is reworked through Badiou's engagement with Lacan. If we accept my earlier claim that the law is sutured to the event, just as time and the subject are ${ }^{6}$, then we can see how the events of mathematics/science, poetry/art, politics and love all 
establish new laws, all of which intensely appear and contradict and break down old established regimes of law. Think of the new laws introduced by Gödel (incompleteness) and Cantor (numerable and non-numerable infinities), which changed the way we understand logic and mathematics. Lacan's reformulation of the laws of desire changed the way we understand love, and massive political events, for example, May '68, produced radical changes in how we viewed law. Finally, the poet Mallarmé changed the laws of poetics. Given space limitations, it is impossible to discuss the law in each of the four principal categories of events that Badiou has established, so I would like to focus on political events. It is here that I believe we can illustrate most forcefully how the law itself can become an event.

According to Badiou, a political event comes about when three conditions have been met. ${ }^{7}$ First, there has to be a radical rupture with a given situation: a political event breaks from an established political regime or order. Second, a political event requires that there be forceful pressure, usually understood as State-pressure, which oppresses a political order or situation. The event pushes against State-pressure and reacts against it. The implication is that there is usually a forceful and often violent reaction against an existing regime that marks the coming to be of an event. Referring to Carl Schmitt's friend-enemy distinction as the origin of politics, Badiou maintains that the distinction must be understood as a multi-faceted negation. He argues that there are many different degrees and ways to understand the difference between the friend and the enemy:

As you know, for Carl Schmitt, the very essence of politics is to clearly distinguish between friend and enemy. But finally, the difficult question is the relationship between the two, precisely when the distinction is clear. Even in the case of war, the question of this relationship is a complex one. And this complexity is the complexity of the action of negativity. For example, in a foreign war, you must often destroy the forces of the enemy, and destruction is certainly the most radical form of negation. But in many civil wars, it is unclear whether the goal is to destroy the enemy, which is a part of your country, or only to dominate it, like in the class struggle, for example. In this case, the negation of the enemy is not in the radical form of destruction, even if civil wars can sometimes be more bloody and cruel than foreign wars. Another example: You can know that a country is your enemy, sometimes in a strong sense, and nevertheless be allied to this country against another enemy more dangerous in the pure present, even if the first enemy is more dangerous in the future. $^{8}$ 
Finally, a political event is collective: it has to involve a collectivity of individuals in order for it to work. Badiou develops his theory of the event in his Logics of Worlds by reminding us that all events have an affective dimension. He lists four kinds of affects that can accompany events: anxiety, courage, justice, and terror. ${ }^{9}$

In order to explain the relation between law and the event, Badiou distinguishes two primary senses of law. There are the laws that regulate the order or regime of elements that constitute a particular set that comes into being through the decision of an event. These general laws, to borrow Badiou's own description, help order the relations between things that constitute a multiplicity. He remarks:

In my own ontology, a thing is a pure multiplicity without any qualitative determination. The general laws of a world are not laws of the things themselves. They are laws of the relations between things in a determinate world. I name the inscription of a pure multiplicity in the relational framework of a world its "appearing" in this world. So, all laws, physical or biological or psychological, or juridical, are laws of appearing in the context of a singular world. In this context, a thing not only is as a pure multiplicity, but also exists as an object in the world. This distinction between being qua being and existence, which is also a distinction between a thing and an object, is fundamental. Always remember that a multiplicity is as such, in a mathematical or ontological context, and exists, or appears, in a concrete world. ${ }^{10}$

General laws of a set allow the arrangement of elements to appear in the order that they exist within a set.

There is, however, a second sense of law, the transgressive sense, which marks the rupture of the decisive event that gives birth to a new order, time and subject. Here, a new law comes upon an established regime in order to bring about a new order. Fidelity to the event and the transgressive law of that event allows for the event to persist through time. Badiou will often refer to revolutions to illustrate his ontology of the event. The Russian Revolutions, just like the French Revolution, displaced a Tsarist order or lawfulness with a revolutionary one. The event of the Russian Revolutions not only created a new epoch or time but also new subjects (the revolutionary socialist/communist subject) and a new order of law - a new lawfulness emerged with the Russian Revolutions. It should be remarked that the event itself never is present or appears in the way that its ordered elements appear. The event stands out of the set, though it structures the set: the event is the ultra-one of the set that constitutes the event itself. 
The practice of law is illuminating for Badiou because it opens up logical possibilities of understanding how events work. He notes that in the practice of the law, for example, that between guilt and innocence, there exist many possible verdicts:

So, if the great field of the law is always a concrete world, or a concrete construction, its logic is not classic. If we take "law" in its strict legal sense, we know that perfectly well. If the sentence P is "guilty," and non-P "innocent," we have always a great number of intermediate values, like "guilty with attenuating circumstances," or "innocent because certainly guilty, but with insufficient proof," and so on. ${ }^{11}$

The practice of law demonstrates that there are degrees of difference between decisions. Badiou mines these differences in order to discuss how events can order a multiplicity of elements belonging to a situation or how they can displace the order of a preceding event.

Events can rupture a given order in very intense, transgressive ways or in less intense, less immediate ways. In addition to the intensity of events, Badiou argues that there are apparent changes or shifts that resemble events, but, in fact, are merely fictions or non-events. The law of an event (not the general sense of the law of the material, historical situation consisting of general multiplicities) is never an ultra-one, like the event itself. Again, the law emerges with the event. Badiou describes the event as a sudden change in the rules of appearing: "Today, and for you, I simplify the matter. I suppose that an event is a sudden change of the rules of appearing; a change of the degrees of existence of a lot of multiplicities which appear in a world." 12 Because an event can only be grasped in retrospective apprehension and never at the moment that the event occurs, there are certain signs or indications that an event has truly occurred. One of these signs is the intensity of a change of the appearing of something that was previously inexistent and which now appears with greater intensity. Badiou uses the examples of the revolutionary worker and the artistic event:

The crucial point is the change of intensity in the existence of something the existence of which was minimal. For example, the political existence of poor workers in a revolutionary event; or the formal existence of abstract figures in a modern artistic event, and so on. I name an "inexistent" of a world a multiplicity which appears in this world with the minimal degree of intensity, something which, in this world, appears as nothing. The question for an event is: what is the destiny, after the event, of an inexistent of the world? [emphasis mine] What becomes 
of the poor worker after the revolution? Are abstract figures, which before the artistic event were not acceptable in a work of art, now essential means of creation $?^{13}$

The discussion of lesser and greater intensity is understood as a test which ultimately can allow us to determine whether or not an event has truly taken place.

There exist three possible degrees of intensity or negations that permit one to know whether an event has taken place or not. The maximum degree of intensity is marked by a radical and transgressive change of an established order. In such events, the inexistent comes to appear with great force and in a new light. Badiou describes the maximum intensity of an event in the following way:

First, the strength of the change is maximal. The test is that among the consequences of this change, we have the maximal value, the maximal intensity of existence, for an object which was an inexistent, which appeared with the minimal degree of intensity. The poor worker, who before the revolution appears as nothing in the political field, becomes the new hero of this field. The abstract painting, which was purely decorative before an artistic revolution, becomes an essential trend of the history of arts, and so on. ${ }^{14}$

Badiou describes maximal intensity of the event as contradictory: the event contradicts a given order.

A second possible degree of intensity is described as intermediate:

Second possibility: the strength of the change is intermediate, neither maximal, nor minimal. The test is that the inexistent takes an intermediate value, more than minimal, less than maximal. The poor worker appears in the political field, but it is not at all a new hero of the field. The abstract figures can be used in painting, but they are not really important. In this case, the logical framework of the event, and of its consequences, is clearly intuitionistic. There is no obligation for the event to be of maximal intensity. In fact, we can have a new intermediate value for the inexistent with the same value for the event. The strength of the event is not a fixed one. So the event is substitutable by other moderate changes. Between this event and the sad "nothing happens," there exist a lot of different possibilities. We can say that a revolutionary politics is classical, but a reformist politics is intuitionistic. I name this change a weak singularity. That is: something 
happens, but without radical effects, and in the general respect of the hierarchy of degrees of appearing in the world. $^{15}$

In the intermediate intensity, small changes may happen, but they do not contradict or upset an established order. The possibilities that emerge in this intuitionistic intensity are manifold, but no single change ruptures the established order. Hence, Badiou's description of maximal, intense change as revolutionary and intuitionistic change as reformist. Reformist politics and, hence, reforms of the law, may modify certain elements within an established regime, but the given order is still faithful to the logic of a more originary event. For example, modifications of laws and the modification of the U.S. Constitution are in and of themselves not revolutionary: they are faithful, understood in the Badiouan sense of fidelity, to the event of the American Revolution and the law, time and subjectivity that emerge contemporaneously with this event.

The last kind of negation is marked by complete lack of intensity of appearing of the inexistent. Badiou calls this kind of negation "paraconsistent." He remarks:

In the third case the strength of the change is not perceptible at the level of the inexistent. After the change the degree of existence of all inexistents of the world is always minimal. The poor worker is nothing more in the political field than a poor worker, abstraction is always nothing in regard to representation and so on. Here the logical framework is paraconsistent. Why? Because we can have a sort of indecidability between event and non-event. Yes, something happens, but, from the point of view of the world, everything is identical. So we have event and nonevent simultaneously. And there are no new values between affirmation and negation, because the world is exactly the same. The principle of excluded middle is true, the principle of contradiction is false; so we have a paraconsistent logic. We say then that we have a false event, or a simulacrum. The lesson is that, when the world is intuitionistic, a true change must be classical, and a false change paraconsistent. ${ }^{16}$

The emphasis here is on the indecidability of the inexistent: its intensity is not fully apparent. Badiou claims, that something has happened, but we are unsure of its effect on the inexistents.

Whether the change is revolutionary (logic of contradiction), reformist (intuitionistic logic) or abstract (paraconsistent logic), the law comes to manifest itself, also in degrees and according to the intensity of the change 
or negation, as that which gives logical coherence or order to the events - an intelligible lawfulness that we can seize in retrospective apprehension. Remarkable in Badiou's analysis is his understanding of law as a kind of logic of negation. The law establishes an order. Again, it should be remarked that this view of law and intelligible lawfulness can be seen already, as Bosteels points out, in Theory of the Subject as well as in Being and Event. In "Meditation 20", Badiou discusses the naming of the event. Naming is fundamental for Badiou, but he reminds readers that though naming is important, naming (and hence the descriptors) attached to the event is not identical to the event itself. To reduce the event to its name and descriptors is "illegal" for Badiou because the event itself can never fully appear, that is, the event itself is unrepresentable. ${ }^{17}$ The law, always understood within the logic of appearing, allows us to test and verify the legality or illegality of an event. In this sense, the law is sutured to the degree of the appearing and non-appearing of the event.

\section{On the Possibility of the Event of Law}

I must confess that I am sympathetic to Badiou's understanding of the event and the legality and illegality it establishes. When we look back at the French Revolution, one of Badiou's favorite examples, we can see how it establishes revolutionary change as it contradicts monarchical rule and law, yet we also see, though time and fidelity to the event that has been named the "French Revolution," a series of intuitionistic reforms and even paraconsistent changes that stem from the contradictory logic of this $18^{\text {th }}$ century event. The work of Sylvain Lazarus shows us how this might happen when we consider the legacy of the French Revolution in history and the law. ${ }^{18}$ Although the law is conditioned by the event here, I wonder whether there can be another place for the law in Badiou's philosophy: Could the law itself be an event and, furthermore, if the law is an event, can it contradict the very logic of the event itself? In other words, with respect to my second question, can the law, understood as an event, establish another kind of logic, intensity of appearing or negation? The implication of my first question bears on a reconsideration of Russell's paradox concerning the relationship of the set of all sets to the sets that it contains.

Badiou begins his article on the law and the three negations with a reference to the friend-enemy distinction made by the German jurist Carl Schmitt. Schmitt also meditates long and hard on the precarious nature of the law and explains the implications of this precariousness for the modern state, which, as Locke notes, sees rule by law as the foundation of the state. Locke tells us in his Two Treatises of Government (see chapter 13, paragraph 158) that salus populi suprema lex. Schmitt makes two important observations: first, the sovereign is the one who can exempt himself from the law, that is, the sovereign is the individual or agent that can exempt itself from the rule 
of law - of course, for Schmitt, there can be no modern rule by law without a sovereign ${ }^{19}$; second, in parliamentary liberal democracies, the law can always be challenged, perhaps not always in a given moment, but as time unfolds and as other precedents are established, even laws confirmed by the Supreme Court can be challenged, rejected or modified. ${ }^{20}$ Schmitt's state of exception, I believe, has the potential to play itself out in terms of the contradictory logic of the event. The German Revolution of 1918 that helped established the constitution of Weimar Germany made provision for a democratic, republican and federalist state - a state that maintained the primacy of law within a parliamentary liberal democratic model of governance. Schmitt argued, against the Nazis and prior to the Nazi takeover in 1933, that a simple majority could not serve as a legitimate means to undo basic principles of constitutional rule. ${ }^{21}$ Even Schmitt's view of the dictator requires some kind of identification of the dictator with the people/community, which was not the case in 1933, as there was significant opposition to Hitler. The event that made National Socialism possible, that gave birth to its totalitarian aspirations, was the contradiction of Weimar constitutional law and the state of exception of the law that was later invoked once Hitler "legitimately" seized power. It was these two fundamental moments, the seizure of government rule though the law and its eventual suspension, leading to the establishment of a new sovereign, namely, Adolf Hitler, that gave rise to other constituent moments of the event that we call fascism or Nazism. It would be a mistake to think that Nazism or fascism is a dead historical moment. It is an event because we see today how various Nazi- or fascist-identified movements throughout Europe (for example, Golden Dawn in Greece, Fiamma Tricolore and Forza Nuova in Italy, along with Nazi identified local parties in east Germany) are surging and growing. These are not paraconsistent or intuitionistic appearings; rather, they are faithful adherents to the event we call fascism, an event that ruptured the way we understand and see politics. ${ }^{22}$

The case of Hitler, understood as the use and abuse of constitutional law and the invoking of the sovereign state of exception, is a most interesting case when it comes to Badiou's claims about the law, for we have here a clear appearing where the contradictory changes of the law can be understood under the logic of the event as described in Badiou's essay on the three negations. The contradiction is two-fold. First, according to Schmitt, there is a contradiction of the legitimate fundamentals of the Weimar constitution and, second, there is a sovereign state of exception, both of which produce a revolution - a revolution that truly altered, and viciously so, the order not only of Germany and Europe, but the whole world. Millions were systematically exterminated as they were considered non-humans: Jews, homosexuals, Roma, Communists, for example. The law was used to justify the extermination of these innocent persons and justify the pursuit of global domination. We see the extension of the use and abuse 
of law by criminals like Eichmann, who argued, at least according to Arendt, that his defense of following the law was thoughtless and introduced for the first time on a massive scale the possibility of what she calls "the banality of evil." ${ }^{23}$ Giorgio Agamben is the contemporary philosopher who understands the impact of the event of the state of exception. His discussion of bare life in Homo Sacer points out the novelty of the contradiction introduced by Schmitt's theory of law and its totalitarian exercise in and after the collapse of Weimar Germany. ${ }^{24}$ What was radically changed by the rise of fascism was the way we viewed human rights and our colossal failure to observe and protect them. Roberto Esposito makes the case that National Socialism changed the relation between life and politics: life now has now become the province of politics, especially biological life. ${ }^{25}$

If the radical and contradicting negations introduced by the state of exception can be understood as an event of law, what are the implications for Badiou's theory of law? I argue that the law need not only be sutured to the event, as time and the subject are insofar as they are extensions of the decision that gives rise to the event, but the law itself is a curious example of an event that can certainly be a set of all sets (i.e., the event of the modern sovereign state of exception) that can be contained within the specific sets that constitute what Badiou calls the intensities, appearings or negations of the law. Even though we name the state of exception as an event, it can never fully appear, yet it conditions very particular constitutive sets and elements of sets that form the event we can generally call National Socialism. Badiou himself never discusses National Socialism as an event, but he certainly would see Mao's and Stalin's Socialist revolutions as events. From an Arendtian perspective, one has to ask why Badiou, perhaps disingenuously so, especially given his own logic, resists the extension of the logic of the event to revolutions of the right. I think this gap betrays perhaps Badiou's own hope for the possibility of a revolutionary politics that can produce new worlds of genuine political life. This being an admirable hope, we still have to concede that his logic of the event also runs the risk of producing ugly and hateful revolutionary change, as evidenced by the lawful sovereign state of exception that gave rise to Hitler's national Socialism, which still has faithful followers today.

If the decisive enactment of the sovereign state of exception of Adolf Hitler can be considered an ultra-one, an event, albeit a miserably tragic one, why can we not say that it simply is a political event? Does this sovereign state of exception not meet the criteria for being considered a political event as discussed above? It would appear that three criteria have been met: collectivity, reacting against state oppression, and massive or contradictory change. But I would argue that the sovereign state of exception is more than just a political event: it changes the very nature of the logic of Badiou's argument. Because the sovereign state of exception is a legal possibility, the law and the event, not only intensely appear, but they also clearly appear. In 
other words, the sovereign state of exception is the one case where the event itself appears precisely because of its explicitly legal formulation and enactment. The sovereign state of exception, seen as an event of law, is a case where the ultra-one becomes clear because its naming and explicit enactment are fully present. The event itself appears and can be named as a one, as an identity.

The foregoing claim about the identity of the one of the sovereign state of exception contradicts Badiou's own licit and legal descriptions of the logic of the event as ultra-one. This is true, but though there is a radical shift in the appearing of the event itself in this case, however, the specific arrangement and multiplicity of elements included in the sets forming the event called the National Socialist sovereign state of exception of 1933 become both discernible and indiscernible. Hannah Arendt makes the case both in the Origins of Totalitarianism and in Eichmann in Jerusalem that the violent and deadly rise of fascism affected and involved, willingly and unwillingly, seemingly disparate and contradictory elements, for example, the complicity of certain Jews and allied powers in the betrayal of the Jewish people. No one is above guilt and reprimand in Arendt's analysis: she highlights massive contradictions and inconsistencies in the arrangement and relationships of sets of actors, persons and groups who one would think would be one side or another of the conflicts produced by the sovereign state of exception that was National Socialism and Stalinism.

The sovereign state of exception of 1933, if we concede that it is an exception to the general logic of Badiou's concept of the event, inverts the structuring and appearing of the event and its constituent elements or sets. Because the sovereign state of exception makes itself clear in a legal and lawful manner, its ultra one status becomes identifiable and one. The force and power of the ultra one as standing outside of its sets of elements while ordering or regimenting them is no longer in the state of exception itself; rather, the sets of constituting elements admit a more intense form of simultaneous and coexisting indiscernibility and discernibility, a contradictory and intense appearing of seeming inconsistencies that adhere with one another, even though they appear inconsistent: Jews betraying Jews, Allies cooperating with the Enemy, friends dealing with enemies, to borrow from Carl Schmitt's concept of the political. When the law itself can become an event, we have an exception to the logic of the event insofar as the event's ultra one is displaced: the event itself becomes a one and its constituent multiplicities of regimented sets and content become both discernible and indiscernible, consistent and inconsistent: they appear as an ultra one, that is, they are not easily identifiable as a specific, situated element: they transcend an easy identification as this or that element. 
${ }^{1}$ Alain Badiou, “The Three Negations,” Cardozo Law Review, vol. 29, no. 5 (2008): 1877-1883.

2 Badiou, "The Three Negations," 1883.

${ }^{3}$ Badiou, “The Three Negations,” 1878.

${ }^{4}$ Badiou, “The Three Negations," 1877.

${ }^{5}$ Bruno Bosteels, “Force of Nonlaw: Badiou's Theory of Justice," Cardozo Law Review, vol. 29, no. 5 (2008): 1905-1926.

6 Antonio Calcagno, "Alain Badiou: The Event of Becoming a Political Subject," Philosophy and Social Criticism, vol. 34 (November 2008): 1051-1071.

${ }^{7}$ Alain Badiou, Abrégé de métapolitique (Paris: Seuil, 1998), 156-160.

${ }^{8}$ Badiou, “The Three Negations," 1877.

9 "Four affects signal the incorporation of a human animal to the subjective process of a truth. The first is evidence of the desire for a Great Point, of a decisive discontinuity, that will install the new world with a single blow, and complete the subject. We will name it terror. The second is evidence of the fear of points, of a retreat before the obscurity of all that is discontinuous, of all that imposes a choice without guarantee between two hypotheses. Or, again, this affect signals the desire for a continuity, for a monotone shelter. We will name it anxiety. The third affirms the acceptance of the plurality of points, that the discontinuities are at once imperious and multiform. We will name it courage. The fourth affirms the desire that the subject be a constant intrication of points and openings. It affirms the equivalence, in regard to the preeminence of the becoming-subject, of what is continuous and negotiated, and of what is discontinuous and violent. It is only there that there are subjective modalities, which depend on the construction of the subject in a world and the capacities of the body to produce effects. They are not to be hierarchized. War can be as good as peace, negotiation as good as struggle, violence as good as gentleness. This affect by which the categories of the act are subordinated to the contingency of worlds, we will name justice." Alain Badiou, Logics of Worlds: Being and Event II, trans. Alberto Toscano (London: Bloomsbury 2013), 96-97.

${ }^{10}$ Badiou, "The Three Negations," 1880.

11 Badiou, "The Three Negations," 1881.

12 Badiou, “The Three Negations," 1882.

13 Badiou, “The Three Negations," 1882.

${ }^{14}$ Badiou, “The Three Negations," 1882.

15 Badiou, “The Three Negations," 1882.

${ }^{16}$ Badiou, “The Three Negations," 1883.

${ }^{17}$ Alain Badiou, L'être et l'événement (Paris: Seuil, 1988), 227.

18 See Antonio Calcagno, “Abolishing Time and History: Lazarus and the Possibility of Thinking Political Events Outside Time,” Journal of French Philosophy, vol. 17, no. 2 (2007): 13-36.

${ }_{19}$ Carl Schmitt, Political Theology: Four Chapters on the Concept of Sovereignty [1922], trans. G. Schwab (Chicago: The University of Chicago Press, 2005), 5-35. 
${ }^{20}$ Carl Schmitt, The Leviathan in the State Theory of Thomas Hobbes, trans. George Schwab and Erna Hilfstein (Chicago: The University of Chicago Press, 2008), 66-77.

${ }^{21}$ Carl Schmitt, Legality and Legitimacy [1932], trans. J. Seitzer (Durham: Duke University Press, 2004), 85-92.

22 Hannah Arendt makes the argument that National Socialism and Fascism were completely new forms of political order because they sought, and could theoretically achieve for the first time through technology, complete world domination. See, Hannah Arendt, The Origins of Totalitarianism (New York: Houghton, Mifflin, Harcourt, 2001).

${ }^{23}$ Hannah Arendt, Eichmann in Jerusalem: A Report on the Banality of Evil (New York: Penguin, 2001).

${ }^{24}$ Giorgio Agamben, Homo Sacer: Sovereign Power and Bare Life, trans. Daniel Heller-Roazen (Palo Alto: Stanford University Press, 1998).

${ }^{25}$ Roberto Esposito, Immunitas, trans. Zakiya Hanafi (Cambridge: Polity Press, 2011). 